Research Article

\title{
Synthesis of a Novel Single-Source Precursor for the Production of Lead Chalcogenide Thin Films
}

\author{
Nathaniel Owusu Boadi $\mathbb{D}^{1},{ }^{1}$ Selina Ama Saah, ${ }^{2}$ and Johannes A. M. Awudza ${ }^{1}$ \\ ${ }^{1}$ Department of Chemistry, Kwame Nkrumah University of Science and Technology, Kumasi, Ghana \\ ${ }^{2}$ Department of Chemical Sciences, University of Energy and Natural Resources, Sunyani, Ghana \\ Correspondence should be addressed to Nathaniel Owusu Boadi; noboadi@gmail.com
}

Received 21 April 2020; Revised 6 July 2020; Accepted 8 July 2020; Published 24 July 2020

Guest Editor: Tapan Sarkar

Copyright ( 2020 Nathaniel Owusu Boadi et al. This is an open access article distributed under the Creative Commons Attribution License, which permits unrestricted use, distribution, and reproduction in any medium, provided the original work is properly cited.

\begin{abstract}
A novel complex $\left[\mathrm{Pb}\left(\left(\mathrm{SeP}^{\mathrm{i}} \mathrm{Pr}_{2}\right)_{2} \mathrm{~N}\right)\left(\mathrm{S}_{2} \mathrm{CNEt}_{2}\right)\right]$ has been synthesized and characterized by microelemental analysis, melting point NMR, and FT-IR spectroscopies. Its crystal structure has also been successfully determined using single-crystal X-ray crystallography. The structure indicates a distorted square pyramidal geometry with the four basal atoms being noncoplanar. The complex was used as a single-source precursor for the deposition of lead chalcogenide thin films on glass substrates at 300, 350, 400 , and $450^{\circ} \mathrm{C}$ by AACVD. The films were characterized by SEM, EDX, and XRD. The XRD peaks matched with cubic PbSe at all temperatures. The SEM micrographs showed the formation of cubes with the lower temperatures $\left(300-350^{\circ} \mathrm{C}\right)$ showing wellresolved cubes while with the higher temperatures $\left(400-450^{\circ} \mathrm{C}\right)$ showing poorly resolved cubes. The EDX analyses confirmed the formation of $\mathrm{PbSe}$ thin films at all the deposition temperatures.
\end{abstract}

\section{Introduction}

Flexible lightweight solar cells that are currently being developed have many uses, which makes them very important. Thin-film solar cells have 30 to 100 times less semiconducting materials and are inexpensive to manufacture than the existing silicon-based cells [1].

The chemical vapour deposition of inorganic/organometallic complexes as dual or multiple source precursors is preferred because of its less vigorous processing parameters. The control of the stoichiometry of the thin films deposited is, however, a challenge that sometimes results in film contamination [2,3]. Single-source precursors are an ideal alternative that addresses this challenge. They have a "builtin" I-III-VI stoichiometry and are well suited for deposition at low temperatures $[3,4]$.

The single-source routes use a metal-organic/organometallic complex as the precursor for the growth of the target compound at the preferred stoichiometry [5]. There are many advantages with the use of single-source precursors over other sources [6-8]. These include preformed bonds that exist within the molecule, which will reduce defects in the material produced.

Also, single-source precursors are mostly stable to air with low toxicity and are easy to handle. Their decomposition pathways are often at low temperatures and cleaner, leading to the production of crystalline nanomaterials with very low impurities [9].

Lead sulfide $(\mathrm{PbS})$ is a IV-VI semiconductor that has technological applications such as infrared detectors [10] and absorbers in thin-film solar cells $[11,12]$. Lead sulfide semiconductor has a narrow gap $[8,13,14]$, which makes it different from other semiconductors. The bandgap of $\mathrm{PbS}$ is affected by temperature and particle size $[12,15]$. The high sensitivity of the properties of $\mathrm{PbS}$ to particle size makes it well suited for nanostructured devices [12]. The multiple exciton generation effects of $\mathrm{PbS}$ and $\mathrm{PbSe}$ semiconductors $[8,16]$ make them preferable as solar cell materials [12].

$\mathrm{PbS}$ has also been used in sensors, photography, detectors, and optical switches in addition to solar cells $[17,18]$. The bandgap of PbS can be tuned easily and thus 
makes it a good material for studying quantum size effects $[14,19]$.

Ternary lead chalcogenide nanocrystals $\left(\mathrm{PbS}_{x} \mathrm{Se}_{1-x}\right)$ [20-22], in comparison with the binary counterparts $\mathrm{PbS}$ $[13,14,19,23,24]$ and PbSe [25], have not been studied extensively. Ternary semiconductor nanomaterials have distinct properties from the binary compounds. These properties include providing alternatives to bandgap control and have effects on size-dependent quantum confinement. Ternary alloys vary with composition, which makes it possible to tune the bandgap, while their size is maintained.

In this work, $\left[\mathrm{Pb}\left(\left(\mathrm{SeP}^{\mathrm{i}} \mathrm{Pr}_{2}\right)_{2} \mathrm{~N}\right)\left(\mathrm{S}_{2} \mathrm{CNEt}_{2}\right)\right]$ single-source precursor has been synthesized and characterized and used to deposit lead chalcogenide thin films using aerosol-assisted chemical vapour deposition (AACVD). The thin films deposited were found to be mainly $\mathrm{PbSe}$.

\section{Experimental}

2.1. Materials. $\left[\mathrm{Pb}\left(\left(\mathrm{SeP}^{\mathrm{i}} \mathrm{Pr}_{2}\right)_{2} \mathrm{~N}\right)_{2}\right]$ and $\left[\mathrm{Pb}\left(\mathrm{S}_{2} \mathrm{CNEt}_{2}\right)_{2}\right]$ were synthesized in the laboratory following the standard reported procedures $[13,26-30]$.

2.2. Instrumentation. The microelemental analysis (CHNS) of the complex was done with a Flash 2000 Thermo Scientific elemental analyser. TGA measurements were carried out using a Seiko SSC/S200 thermal analyser from 30 to $600^{\circ} \mathrm{C}$ at a heating rate of $10^{\circ} \mathrm{C} \mathrm{min}^{-1}$ and a nitrogen flow rate of $10 \mathrm{~mL} / \mathrm{min}$.

The Bruker AXS D8 diffractometer fitted with $\mathrm{Cu}-\mathrm{K} \alpha$ radiation $(\lambda=1.5418 \AA)$ source at $40 \mathrm{kV}$ and $40 \mathrm{~mA}$ at room temperature was used for the powder X-ray diffraction (p-XRD) analyses of the samples. The thin-film samples were scanned from 20 to $80^{\circ}$ with a step size of $0.02^{\circ}$ and a dwell time of $3 \mathrm{~s}$. The Philips (FEI) XL 30 fieldemission gun equipped with a DX4 EDX detector was used for SEM and EDX analyses. Before the SEM and EDX analyses, the samples were carbon-coated using an Edwards coating system E306A. The absorbance measurements were done on the PerkinElmer UV-VIS-NIR lambda 1050 spectrophotometer.

2.3. Synthesis of $\left[\mathrm{Pb}\left(\left(\mathrm{SeP}^{i} \mathrm{Pr}_{2}\right)_{2} \mathrm{~N}\left(\mathrm{~S}_{2} \mathrm{CNEt} t_{2}\right)\right]\right.$ Complex. In a typical synthesis, equal moles $(1: 1)$ of the reactant complexes $\left(\left[\mathrm{Pb}\left(\left(\mathrm{SeP}^{\mathrm{i}} \mathrm{Pr}_{2}\right)_{2} \mathrm{~N}\right)_{2}\right]\right.$ and $\left[\mathrm{Pb}\left(\mathrm{S}_{2} \mathrm{CNEt}_{2}\right)_{2}\right]$ were dissolved in chloroform in a round-bottom flask and refluxed for two hours. The solution was cooled to room temperature and precipitated with methanol. The precipitate obtained was filtered out of solution and dried under vacuum. Elemental analysis for $\mathrm{C}_{17} \mathrm{H}_{28} \mathrm{~N}_{2} \mathrm{P}_{2} \mathrm{~S}_{2} \mathrm{Se}_{2} \mathrm{~Pb}(\mathrm{Mw}=761.66)$. Calculated: $\mathrm{C}=26.81, \mathrm{H}=5.03, \mathrm{~N}=3.68, \mathrm{~S}=8.42, \mathrm{P}=8.13$, and $\mathrm{Pb}=27.20 \%$; observed: $\mathrm{C}=26.85, \mathrm{H}=5.11, \mathrm{~N}=3.71$, $\mathrm{S}=8.17, \mathrm{P}=8.16$, and $\mathrm{Pb}=27.01 \% .{ }^{1} \mathrm{H} \mathrm{NMR}\left(\mathrm{CDCl}_{3}\right)$ : $1.11-1.23(\mathrm{~m}, 24 \mathrm{H}), 1.24-1.27$ (m, $6 \mathrm{H}), 2.09-2.21(\mathrm{~m}, 4 \mathrm{H})$, 3.69-3.81 (m, $4 \mathrm{H}) ;{ }^{31} \mathrm{P}\{1 \mathrm{H}\}$ NMR $\left(\mathrm{CDCl}_{3}\right): 55.38 \mathrm{ppm}$ (satellite peaks $57.15,53.97 \mathrm{ppm}) ;{ }^{77} \mathrm{Se} \mathrm{NMR}\left(\mathrm{CDCl}_{3}\right)$ : $-175.80,-182.49 \mathrm{ppm} ; v(\mathrm{C}-\mathrm{N}) 1142 \mathrm{~cm}^{-1}, v(\mathrm{C}-\mathrm{S}) 1015 \mathrm{~cm}^{-1}$; melting point $=129-131^{\circ} \mathrm{C}$.
2.4. AACVD Procedure. In this procedure, an aerosol is generated from a $200 \mathrm{mmol}$ solution of $\left[\mathrm{Pb}\left(\left(\mathrm{SeP}^{\mathrm{i}} \mathrm{Pr}_{2}\right)_{2} \mathrm{~N}\right)\right.$ $\left.\left(\mathrm{S}_{2} \mathrm{CNEt}_{2}\right)\right]$ in $10 \mathrm{ml}$ tetrahydrofuran using an ultrasonic humidifier (PIFCO ultrasonic humidifier model no. 1077) with argon gas as the inert gas that pushes the aerosol. A quartz tube containing glass substrates of sizes approximately $1 \times 3 \mathrm{~cm}$ is connected to the flask containing the aerosol through a flexible tube and is placed within a Carbolite tube furnace. Argon gas at a flow rate of $180 \mathrm{~cm}^{3} /$ min is passed through the aerosol and the quartz tube, while the aerosol material deposits on the glass substrate at constant temperatures. The depositions were done at temperatures of $300,350,400$, and $450^{\circ} \mathrm{C}$ for 30 minutes.

2.5. Single-Crystal X-Ray Diffraction Studies. Single crystals of $\left[\mathrm{Pb}\left(\left(\mathrm{SeP}^{\mathrm{i}} \mathrm{Pr}_{2}\right)_{2} \mathrm{~N}\right)\left(\mathrm{S}_{2} \mathrm{CNEt}_{2}\right)\right]$ suitable for X-ray diffraction studies were obtained by slow evaporation of chloroform/ methanol $(1: 2)$ mixture containing dissolved complex. A Bruker Smart Apex diffractometer fitted with a Mo K $\alpha$ X-ray source and a CCD collector were used for the determination of the crystal structure. The SHELXTL package version 6.10 was used to calculate the structure. Direct methods were employed and the refinement was done by full-matrix leastsquares on $F^{2}$. The hydrogen atoms were placed at calculated positions and assigned isotropic thermal parameters. Other atoms were refined using anisotropic atomic displacement parameters.

\section{Results and Discussion}

The single-crystal structure of $\left[\mathrm{Pb}\left(\left(\mathrm{SeP}^{\mathrm{i}} \mathrm{Pr}_{2}\right)_{2} \mathrm{~N}\right)\left(\mathrm{S}_{2} \mathrm{CNEt}_{2}\right)\right]$ has been determined and reported (Figure 1). The geometry at the lead atom in the complex is a distorted square pyramidal with four chalcogenide $(\mathrm{S}, \mathrm{Se}$ ) atoms, forming the base of the pyramid and the lone pair on the lead atom occupying the axial position.

In the complex, the lead atom is coordinated to two sulphur atoms and two selenium atoms, the selenium atoms coming from $\left[\mathrm{Pb}\left(\left(\mathrm{SeP}^{\mathrm{i}} \mathrm{Pr}_{2}\right)_{2} \mathrm{~N}\right)_{2}\right]$ and the sulphur atoms from $\left[\mathrm{Pb}\left(\mathrm{S}_{2} \mathrm{CNEt}_{2}\right)_{2}\right]$ to form dimeric units. The structure indicates a distorted pyramidal geometry although the basal four atoms are not coplanar. The crystalline phase of the compound has the monoclinic crystal system and $P 2(1) / n$ space group. The crystal structure refinement data are shown in Table 1.

The selected bond lengths and bond angles are shown in Table 2. The Pb-S bond lengths are 2.6317 and $2.9139 \AA$ and within experimental error are significantly different from each other. The bond lengths indicate that one $S$ atom is closely attached to the lead atom to form a relatively strong coordinate bond while the other $\mathrm{S}$ atom is relatively distant from the central atom. The structure also shows that the two $\mathrm{Pb}-\mathrm{Se}$ bonds are significantly longer than the $\mathrm{Pb}-\mathrm{S}$ bonds. This suggests that the $S$ atoms may be relatively strongly bound to $\mathrm{Pb}$ than the Se atoms. The bond length of $\mathrm{Pb}-\mathrm{Se}$ may be as a result of steric factors since the Se atom has a larger atomic radius compared to the $\mathrm{S}$ atom. The $\mathrm{Pb}-\mathrm{S}$ bond lengths obtained are similar to the ones obtained for lead (II) 


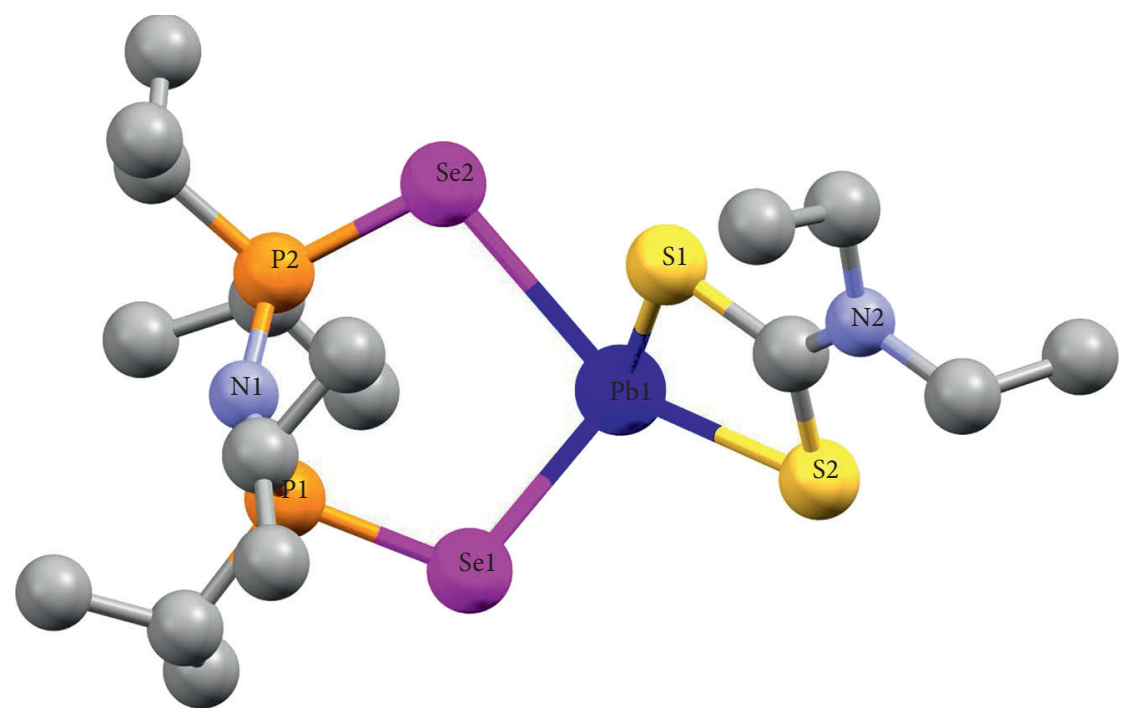

FIgURE 1: An ORTEP thermal ellipsoid structure of $\left[\mathrm{Pb}\left({ }^{\mathrm{i}} \mathrm{Pr}_{2} \mathrm{PSeN}^{\mathrm{i}} \mathrm{Pr}_{2} \mathrm{PSe}\right)\left(\mathrm{S}_{2} \mathrm{CNEt}_{2}\right)\right]$. CCDC number 1918928.

TABle 1: Crystal structure data for $\mathrm{C}_{17} \mathrm{H}_{38} \mathrm{~N}_{2} \mathrm{P}_{2} \mathrm{PbS}_{2} \mathrm{Se}_{2}$.

\begin{tabular}{lc}
\hline Chem. formula & $\mathrm{C}_{17} \mathrm{H}_{38} \mathrm{~N}_{2} \mathrm{P}_{2} \mathrm{PbS}_{2} \mathrm{Se}_{2}$ \\
Formula wt. & 761.66 \\
Cryst. syst. & Monoclinic \\
Space group & $P 2(1) / n$ \\
$\mathrm{a}(\AA)$ & $14.6415(4)$ \\
$\mathrm{b}(\AA)$ & $12.9568(3)$ \\
$\mathrm{c}(\AA)$ & $15.8270(4)$ \\
$\alpha(\mathrm{deg})$ & 90 \\
$\beta($ deg $)$ & $117.5180(10)$ \\
$\gamma($ deg $)$ & 90 \\
$\mathrm{~V}\left(\AA^{3}\right)$ & $2662.81(12)$ \\
$\mathrm{Z}$ & 4 \\
$\mathrm{D}_{\text {calcd }}(\mathrm{g} \mathrm{cm}$ & $-3)$ \\
$\mu(\mathrm{Mo} \mathrm{K} \alpha)\left(\mathrm{mm}^{-1}\right)$ & 1.900 \\
$\mathrm{R} 1(I>2 \sigma(I))^{\mathrm{b}}$ & 18.086 \\
wR2 $($ all data $)$ & 0.0417 \\
$\mathrm{GOF}$ on $F^{2}$ & 0.1228 \\
\hline
\end{tabular}

TABLE 2: Selected bond lengths $(\AA)$ and angles $\left({ }^{\circ}\right)$.

\begin{tabular}{lc}
\hline $\mathrm{P}(1)-\mathrm{Se}(1)$ & $2.2029(15)$ \\
$\mathrm{P}(1)-\mathrm{Se}(1)$ & $2.2029(15)$ \\
$\mathrm{P}(2)-\mathrm{Se}(2)$ & $2.1728(13)$ \\
$\mathrm{Pb}(1)-\mathrm{S}(1)$ & $2.6317(14)$ \\
$\mathrm{Pb}(1)-\mathrm{Se}(1)$ & $2.8257(7)$ \\
$\mathrm{Pb}(1)-\mathrm{S}(2)$ & $2.9139(13)$ \\
$\mathrm{Pb}(1)-\mathrm{Se}(2)$ & $3.0115(6)$ \\
$\mathrm{S}(1)-\mathrm{Pb}(1)-\mathrm{Se}(1)$ & $99.95(4)$ \\
$\mathrm{S}(1)-\mathrm{Pb}(1)-\mathrm{S}(2)$ & $64.61(4)$ \\
$\mathrm{Se}(1)-\mathrm{Pb}(1)-\mathrm{S}(2)$ & $89.58(3)$ \\
$\mathrm{S}(1)-\mathrm{Pb}(1)-\mathrm{Se}(2)$ & $74.94(3)$ \\
$\mathrm{Se}(1)-\mathrm{Pb}(1)-\mathrm{Se}(2)$ & $99.109(17)$ \\
$\mathrm{S}(2)-\mathrm{Pb}(1)-\mathrm{Se}(2)$ & $139.52(3)$ \\
$\mathrm{C}(13)-\mathrm{S}(1)-\mathrm{Pb}(1)$ & $92.37(18)$ \\
$\mathrm{C}(13)-\mathrm{S}(2)-\mathrm{Pb}(1)$ & $83.76(18)$ \\
$\mathrm{P}(1)-\mathrm{Se}(1)-\mathrm{Pb}(1)$ & $108.20(4)$ \\
$\mathrm{P}(2)-\mathrm{Se}(2)-\mathrm{Pb}(1)$ & $103.01(4)$ \\
\hline
\end{tabular}

diethyldithiocarbamate complex [31] and the $\mathrm{Pb}-\mathrm{Se}$ bond lengths in the complex compared favorably with the $\mathrm{Pb}$ $\left[\left(\mathrm{SeP}^{\mathrm{i}} \mathrm{Pr}_{2}\right)_{2} \mathrm{~N}\right]_{2}$ complex [32].

The average bond angle around the $\mathrm{S} / \mathrm{Se}-\mathrm{Pb}-\mathrm{S} / \mathrm{Se}$ is $94.62^{\circ}$, which is greater than the value obtained for the lead (II) diethyldithiocarbamate complex $\left(87.85^{\circ}\right)$ and less than the value obtained for $\mathrm{Pb}\left[\left(\mathrm{SeP}^{\mathrm{i}} \mathrm{Pr}_{2}\right)_{2} \mathrm{~N}\right]_{2}\left(103.82^{\circ}\right)$. The $\mathrm{S}(1)$ $\mathrm{Pb}(1)-\mathrm{S}(2)$ bond angle in our complex $\left(64.61^{\circ}\right)$ was comparable to the one obtained for lead (II) diethyldithiocarbamate complex $\left(64.1^{\circ}\right)$ [31]; however, the Se(1)$\mathrm{Pb}(1)-\mathrm{Se}(2)$ bond angle in our complex $\left(99.109^{\circ}\right)$ was greater than the one in the $\mathrm{Pb}\left[\left(\mathrm{SeP}^{\mathrm{i}} \mathrm{Pr}_{2}\right)_{2} \mathrm{~N}\right]_{2}$ complex of $96.05^{\circ}$ [32]. These bond lengths and angles indicate a clear distinction between the complex formed and its parent complexes.

3.1. Thermogravimetric Analysis. Thermogravimetric analysis of $\left[\mathrm{Pb}\left(\left(\mathrm{SeP}^{\mathrm{i}} \mathrm{Pr}_{2}\right)_{2} \mathrm{~N}\right)\left(\mathrm{S}_{2} \mathrm{CNEt}_{2}\right)\right]$ showed a two-step decomposition (Figure 2). The onset and endset temperatures for the first decomposition step were $273.14^{\circ} \mathrm{C}$ and $313.14^{\circ} \mathrm{C}$, respectively, with a corresponding weight loss of $23.06 \%$. This could be attributed to the loss of the $\left[\mathrm{CNEt}_{2}\right]$ moiety and some sulphur gases. The rate of decomposition for the first step was relatively slow with a decomposition temperature of $310.21^{\circ} \mathrm{C}$. There was further loss of weight of $11.41 \%$ from the endset of the first decomposition and onset of the second decomposition. The unsteady transition is due to the thermal instability of the complex at that temperature. The second decomposition step had an onset temperature of $353.21^{\circ} \mathrm{C}$ and an endset temperature of $376.23^{\circ} \mathrm{C}$. The corresponding weight loss was $32.33 \%$. This could be attributed to the loss of the $\left[{ }^{\mathrm{i}} \mathrm{Pr}_{2} \mathrm{PNP}^{\mathrm{i}} \mathrm{Pr}_{2}\right]$ moiety. The rate of decomposition for the second step was fast with a decomposition temperature of $373.32^{\circ} \mathrm{C}$. A stable residue was obtained at $376^{\circ} \mathrm{C}$. The remaining residue for 


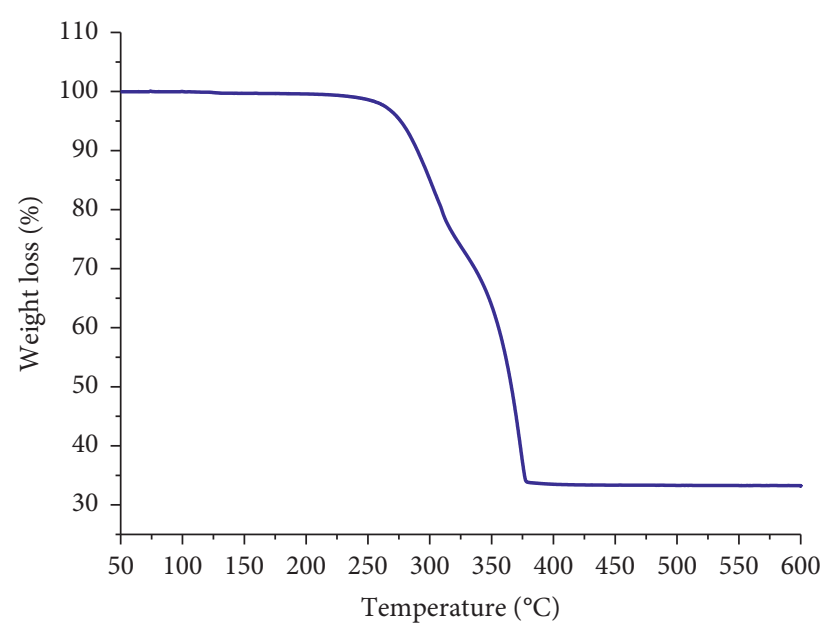

Figure 2: TGA profile for $\left[\mathrm{Pb}\left(\left(\mathrm{SeP}^{\mathrm{i}} \mathrm{Pr}_{2}\right)_{2} \mathrm{~N}\right)\left(\mathrm{S}_{2} \mathrm{CNEt}_{2}\right)\right]$ complex.

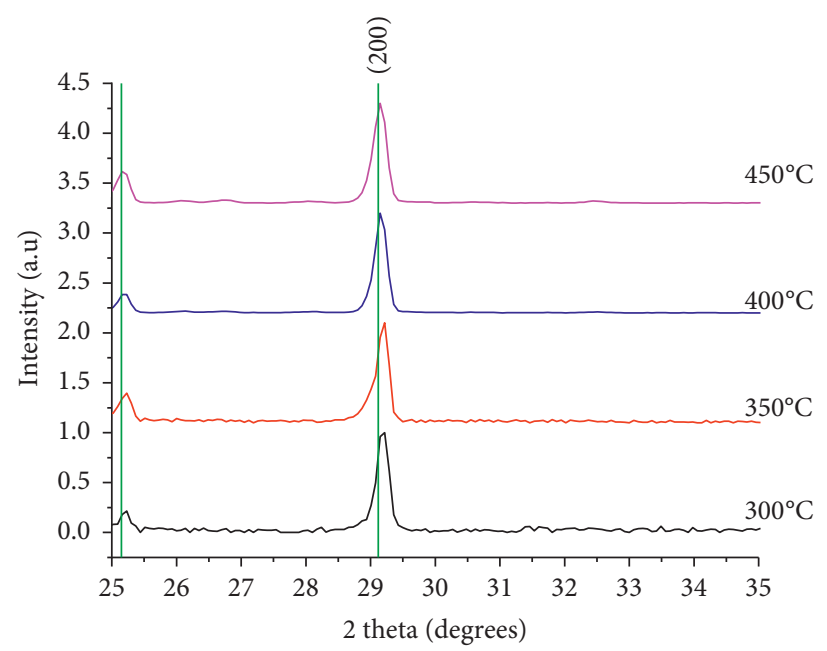

FIgURE 3: A stacked set of four p-XRD spectra showing the diffracting pattern of thin films deposited from $\left[\mathrm{Pb}\left(\left(\mathrm{SeP}^{\mathrm{i}} \mathrm{Pr}_{2}\right)_{2} \mathrm{~N}\left(\mathrm{~S}_{2} \mathrm{CNEt} \mathrm{t}_{2}\right)\right]\right.$ complex at $300,350,400$, and $450^{\circ} \mathrm{C}$. The standard pattern is PbSe (ICDD 04-004-4328).

$\left[\mathrm{Pb}\left(\left(\mathrm{SeP}^{\mathrm{i}} \mathrm{Pr}_{2}\right)_{2} \mathrm{~N}\right)\left(\mathrm{S}_{2} \mathrm{CNEt}_{2}\right)\right]$ (33.2\%) was lower than the theoretical values of $37.57 \%$ and $34.5 \%$ for $\mathrm{PbS}$ and $\mathrm{PbS}_{x} \mathrm{Se}_{1-x}$, respectively. This may be due to the volatility at elevated temperatures $\left(600^{\circ} \mathrm{C}\right)$, thereby leading to a further weight loss.

The p-XRD for the thin films deposited from $\left[\mathrm{Pb}\left(\left(\mathrm{SeP}^{\mathrm{i}} \mathrm{Pr}_{2}\right)_{2} \mathrm{~N}\right) \quad\left(\mathrm{S}_{2} \mathrm{CNEt}_{2}\right)\right]$ complex at the selected temperatures $\left(300-450^{\circ} \mathrm{C}\right)$ matched mainly with standard lead selenide peaks. There was, however, some slight shift of the shoulders of the peaks from the standard PbSe peaks (shown as vertical lines) at lower temperatures $\left(300-350^{\circ} \mathrm{C}\right)$. This shift may be due to the formation $\mathrm{PbS}_{x} \mathrm{Se}_{1-x}$ at these temperatures; however, the peaks did not match with a standard PbSSe spectrum. A stacked set of p-XRD spectra of the thin films deposited at various temperatures is shown in Figure 3.
Scanning electron microscope (SEM) images of the thin films deposited from $\left[\mathrm{Pb}\left(\left(\mathrm{SeP}^{\mathrm{i}} \mathrm{Pr}_{2}\right)_{2} \mathrm{~N}\left(\mathrm{~S}_{2} \mathrm{CNEt}_{2}\right)_{2}\right)\right]$ (Figure 4) showed cubic lead chalcogenide crystals at all the deposition temperatures. Although the lower temperatures $\left(300-350^{\circ} \mathrm{C}\right)$ showed poor substrate coverage, the cubes were very uniform and well resolved. Also, the side length of the cubes increased as temperature also increased from 300 to $350^{\circ} \mathrm{C}$ which was expected. However, at higher temperatures $\left(400-450^{\circ} \mathrm{C}\right)$, the image showed almost total coverage of the glass substrate with nonuniformly sized cubes. Generally, the level of size variation was significant. It was as if smaller well-resolved cubes were combined in a nonspecific order to form larger truncated cubes. This observation may be possible due to the increase in surface energy as the particle size decreases. 


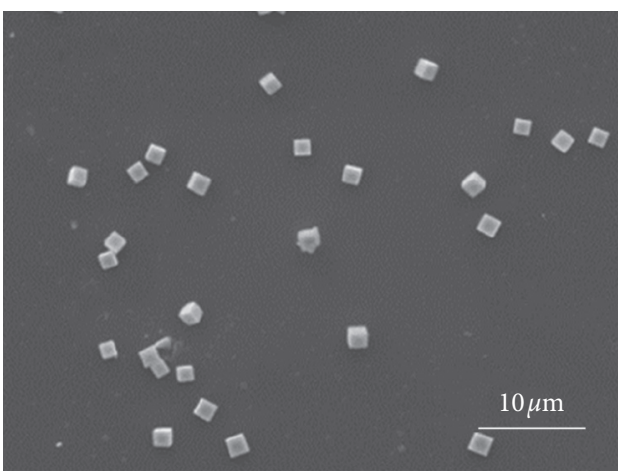

(a)

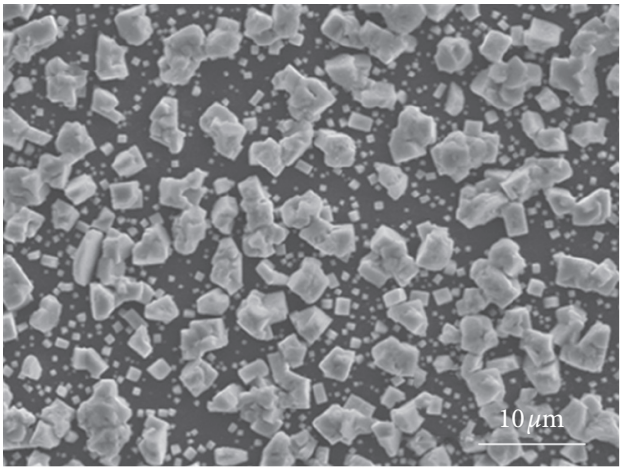

(c)

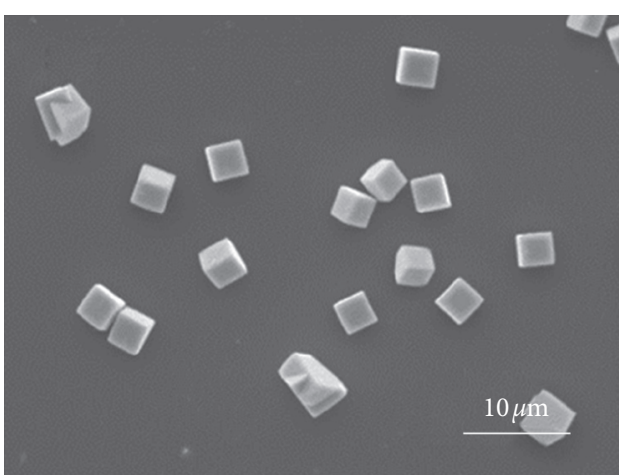

(b)

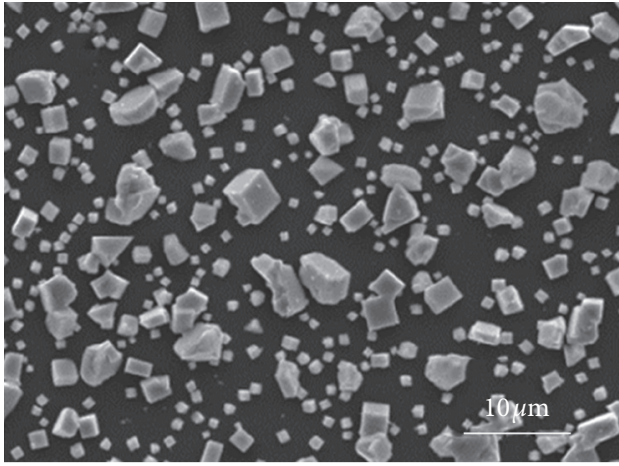

(d)

Figure 4: SEM images at 5000x magnification of thin films deposited from $\left[\mathrm{Pb}\left(\left(\mathrm{SeP}^{\mathrm{i}} \mathrm{Pr}_{2}\right)_{2} \mathrm{~N}\left(\mathrm{~S}_{2} \mathrm{CNEt}_{2}\right)\right)\right]$ at (a) $300^{\circ} \mathrm{C}$, (b) $350^{\circ} \mathrm{C},(\mathrm{c}) 400^{\circ} \mathrm{C}$, and $(\mathrm{d}) 450^{\circ} \mathrm{C}$.

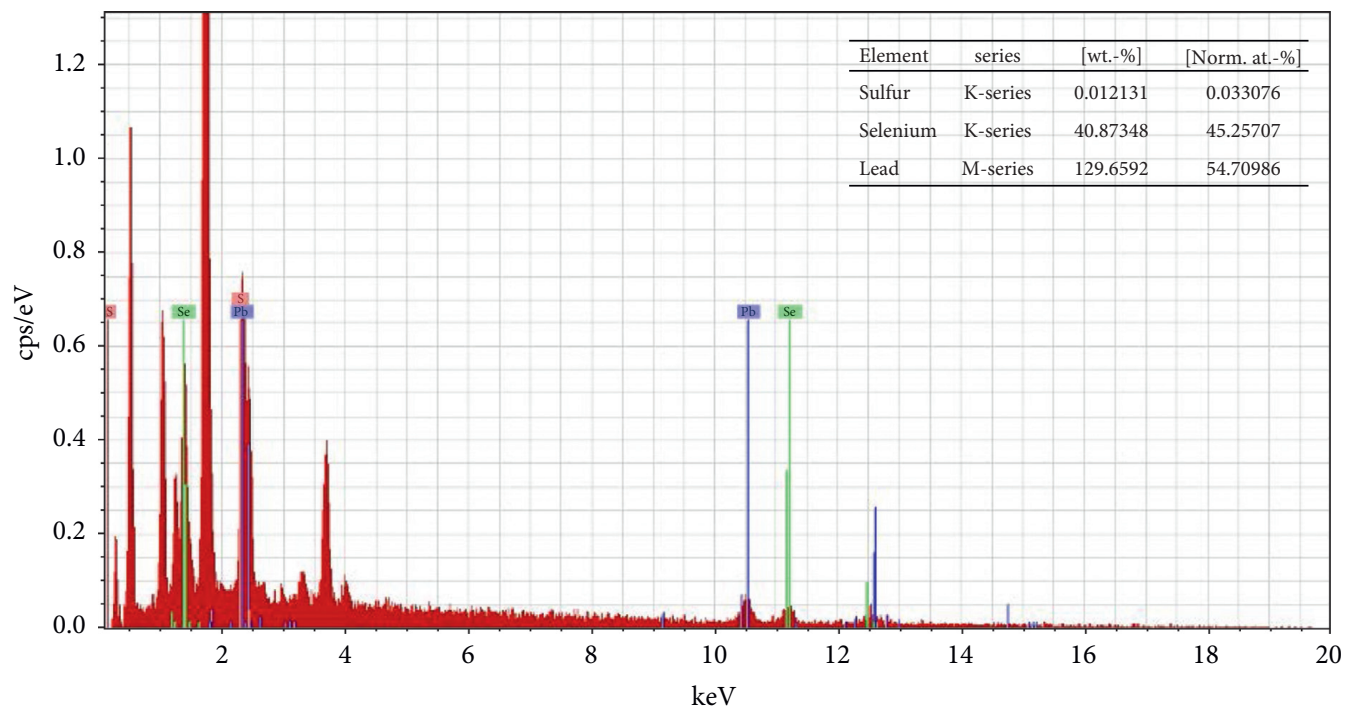

Figure 5: EDAX spectrum of thin films deposited from $\left[\mathrm{Pb}\left(\left(\mathrm{SeP}^{\mathrm{i}} \mathrm{Pr}_{2}\right)_{2} \mathrm{~N}\left(\mathrm{~S}_{2} \mathrm{CNEt}_{2}\right)\right)\right]$ at $300^{\circ} \mathrm{C}$. Inset: a table showing the elemental composition of the thin film.

Energy-dispersive X-ray spectroscopy (EDAX) quantification on the thin films indicated $0.03 \%$ sulphur content at $300^{\circ} \mathrm{C}$ (Figure 5). However, at higher temperatures, there was no sulphur present, leading to the formation of $\mathrm{PbSe}$ thin films. The absence of sulphur at $450^{\circ} \mathrm{C}$ may be as a result of the high temperature breaking the $\mathrm{Pb}-\mathrm{S}$ bond and thereby causing the sulphur to volatilize [33].

\section{Conclusion}

A novel complex $\left[\mathrm{Pb}\left(\left(\mathrm{SeP}^{\mathrm{i}} \mathrm{Pr}_{2}\right)_{2} \mathrm{~N}\left(\mathrm{~S}_{2} \mathrm{CNEt}_{2}\right)\right]\right.$ has been successfully synthesized and characterized. The crystal structure obtained for the complex indicates a distorted square pyramidal geometry, with the central atom $(\mathrm{Pb})$ bonded directly to two sulphur atoms cis to each other and 
two selenium atoms cis to each other. The complex was used as a single-source precursor to deposit lead chalcogenide thin films by AACVD at 300, 350, 400, and $450^{\circ} \mathrm{C}$. The thin films were characterized by using p-XRD, SEM, and EDAX. The thin films formed at all the deposition temperatures were $\mathrm{PbSe}$ with traces of sulphur at $300^{\circ} \mathrm{C}$.

\section{Data Availability}

The data used to support the findings of this study are available from the corresponding author upon request.

\section{Conflicts of Interest}

The authors declare that they have no conflicts of interest.

\section{Acknowledgments}

The authors wish to thank the Royal Society (London) Leverhulme Africa Award Program for their financial support. The authors sincerely thank Prof. Paul O'Brien, FRS, CBE, of blessed memory for the immense support and guidance he gave for this work.

\section{References}

[1] M. A. Contreras, B. Egaas, K. Ramanathan et al., "Progress toward $20 \%$ efficiency in $\mathrm{Cu}(\mathrm{In}, \mathrm{Ga}) \mathrm{Se}_{2}$ polycrystalline thin film solar cells," Progress in Photovoltaics: Research and Applications, vol. 7, no. 4, pp. 311-316, 1999.

[2] K. Banger, J. Hollingsworth, J. Harris, W. E. Buhro, and A. F. Hepp, "Single source precursors for thin-film solar cells," NASA/TM-211496, 2002.

[3] K. K. Banger, J. A. Hollingsworth, J. D. Harris, J. Cowen, W. E. Buhro, and A. F. Hepp, "Ternary single-source precursors for polycrystalline thin-film solar cells," Applied Organometallic Chemistry, vol. 16, no. 11, pp. 617-627, 2002.

[4] J. A. Hollingsworth, K. K. Banger, M. H.-C. Jin et al., "Single source precursors for fabrication of I-III-VI2 thin-film solar cells via spray CVD," Thin Solid Films, vol. 431-432, pp. 63-67, 2003.

[5] P. O'Brien and R. Nomura, "Single-molecule precursor chemistry for the deposition of chalcogenide(S or Se)-containing compound semiconductors by MOCVD and related methods," Journal of Materials Chemistry, vol. 5, no. 11, pp. 1761-1773, 1995.

[6] A. M. Arif, B. L. Benac, A. H. Cowley et al., "Mono-and dinuclear phosphido and arsenido complexes of gallium; $\mathrm{Ga}\left(\mathrm{EBu}_{2}^{\mathrm{t}}\right)_{3}, \mathrm{Ga}\left[\mathrm{PH}\left(2,4,6-\mathrm{Bu}_{3}^{\mathrm{t}} \mathrm{C}_{6} \mathrm{H}_{2}\right)\right]_{3}$ and $\left[\mathrm{Ga}\left(\mu-\mathrm{EBu}_{2}^{\mathrm{t}}\right) \mathrm{R}_{2}\right]_{2}$, $\left(\mathrm{E}=\mathrm{P}, \mathrm{As} ; \mathrm{R}=\mathrm{Me}, \mathrm{Bu}^{\mathrm{n}}\right)$," Journal of the Chemical Society, Chemical Communications, vol. 1543, no. 20, pp. 1543-1545, 1986.

[7] A. H. Cowley and R. A. Jones, "Single-source III/V precursors: a new approach to gallium arsenide and related semiconductors," Angewandte Chemie International Edition in English, vol. 28, no. 9, pp. 1208-1215, 1989.

[8] N. O. Boadi, M. A. Malik, P. O'Brien, and J. A. M. Awudza, "Single source molecular precursor routes to lead chalcogenides," Dalton Transactions (Cambridge, England: 2003), vol. 41, no. 35, pp. 10497-10506, 2012.
[9] N. L. Pickett and P. O’Brien, "Syntheses of semiconductor nanoparticles using single-molecular precursors," The Chemical Record, vol. 1, no. 6, pp. 467-479, 2001.

[10] X. Liu and M. Zhang, "Studies on PbS and PbSe detectors for IR system," International Journal of Infrared and Millimeter Waves, vol. 21, no. 10, pp. 1697-1701, 2000.

[11] S. Günes, K. P. Fritz, H. Neugebauer, N. S. Sariciftci, S. Kumar, and G. D. Scholes, "Hybrid solar cells using PbS nanoparticles," Solar Energy Materials and Solar Cells, vol. 91, no. 5, pp. 420-423, 2007.

[12] J. Hernández-Borja, Y. V. Vorobiev, and R. Ramírez-Bon, "Thin film solar cells of CdS/PbS chemically deposited by an ammonia-free process," Solar Energy Materials and Solar Cells, vol. 95, no. 7, pp. 1882-1888, 2011.

[13] N. O. Boadi, P. D. McNaughter, M. Helliwell, M. A. Malik, J. A. M. Awudza, and P. O’Brien, “The deposition of PbS and $\mathrm{PbSe}$ thin films from lead dichalcogenoimidophosphinates by AACVD," Inorganica Chimica Acta, vol. 453, pp. 439-442, 2016.

[14] S. A. Saah, N. O. Boadi, and C. Wilkins, "Deposition of pbs thin films from lead hexadecyl and octadecyl xanthate complexes using the spin coating method," MRS Advances, vol. 4, no. 11-12, pp. 733-742, 2019.

[15] N. O. Boadi, S. A. Saah, M. Helliwell, and J. A. M. Awudza, "Hot-injection synthesis of $\mathrm{PbE}(\mathrm{E}=\mathrm{S}, \mathrm{Se})$ nanoparticles from dichalcogenoimidophosphinato lead (II) complexes," ChemistrySelect, vol. 4, no. 47, pp. 13908-13911, 2019.

[16] R. J. Ellingson, M. C. Beard, J. C. Johnson et al., "Highly efficient multiple exciton generation in colloidal $\mathrm{PbSe}$ and $\mathrm{PbS}$ quantum dots," Nano Letters, vol. 5, no. 5, pp. 865-871, 2005.

[17] A. De Iacovo, C. Venettacci, L. Colace, L. Scopa, and S. Foglia, "High responsivity fire detectors based on $\mathrm{PbS}$ colloidal quantum dot photoconductors," IEEE Photonics Technology Letters, vol. 29, no. 9, pp. 703-706, 2017.

[18] B. H. Xie, G. T. Fei, S. H. Xu, X. D. Gao, J. X. Zhang, and L. D. Zhang, "Tunable broadband wavelength-selective enhancement of responsivity in ordered Au-nanorod arraymodified PbS photodetectors," Journal of Materials Chemistry C, vol. 6, no. 7, pp. 1767-1773, 2018.

[19] J. Akhtar, M. A. Malik, P. O’Brien, and M. Helliwell, "Controlled synthesis of $\mathrm{PbS}$ nanoparticles and the deposition of thin films by Aerosol-Assisted Chemical Vapour Deposition (AACVD)," Journal of Materials Chemistry, vol. 20, no. 29, pp. 6116-6124, 2010.

[20] M. Brumer, A. Kigel, L. Amirav et al., "PbSe/PbS and PbSe/ PbSexS1-x core/shell nanocrystals," Advanced Functional Materials, vol. 15, no. 7, pp. 1111-1116, 2005.

[21] S. A. Saah, M. D. Khan, P. D. McNaughter, J. A. M. Awudza, N. Revaprasadu, and P. O'Brien, "Facile synthesis of a $\mathrm{PbS} 1-\mathrm{xSex}(0 \leq \mathrm{x} \leq 1)$ solid solution using bis(N,N-diethyl$\mathrm{N}^{\prime}$-naphthoylchalcogenoureato)lead(ii) complexes," New Journal of Chemistry, vol. 42, no. 20, pp. 16602-16607, 2018.

[22] S. A. Saah, P. D. McNaughter, M. A. Malik, J. A. M. Awudza, N. Revaprasadu, and P. O’Brien, "PbS x Se1-x thin films from the thermal decomposition of lead(II) dodecylxanthate and bis(N,N-diethyl-N' ${ }^{\prime}$-naphthoylselenoureato)lead(II) precursors," Journal of Materials Science, vol. 53, no. 6, pp. 42834293, 2018.

[23] P. D. McNaughter, S. A. Saah, M. Akhtar et al., "The effect of alkyl chain length on the structure of lead(ii) xanthates and their decomposition to $\mathrm{PbS}$ in melt reactions," Dalton Transactions, vol. 45, no. 41, pp. 16345-16353, 2016.

[24] J. Akhtar, M. Afzaal, M. A. Vincent, N. A. Burton, I. H. Hillier, and $\mathrm{P}$. O'Brien, "Low temperature CVD growth of PbS films 
on plastic substrates," Chemical Communications, vol. 47, no. 7, pp. 1991-1993, 2011.

[25] W. Ma, J. M. Luther, H. Zheng, Y. Wu, and A. P. Alivisatos, "Photovoltaic devices employing ternary PbSxSe1-x nanocrystals," Nano Letters, vol. 9, no. 4, pp. 1699-1703, 2009.

[26] D. Cupertino, D. J. Birdsall, A. M. Z. Slawin, and J. D. Woollins, "The preparation and coordination chemistry of $\operatorname{Pr} 2 \mathrm{P}(\mathrm{E}) \mathrm{NHP}(\mathrm{E} \%)$ i $\operatorname{Pr} 2(\mathrm{E}, \mathrm{E} \%=\mathrm{Se} ; \mathrm{E}=\mathrm{Se}, \mathrm{E} \%=\mathrm{S}$; $\mathrm{E}=\mathrm{S}, \mathrm{E} \%=\mathrm{O} ; \mathrm{E}, \mathrm{E} \%=\mathrm{O}$," Inorganica Chimica Acta, vol. 290 , no. 1 , pp. $1-7,1999$.

[27] D. Cupertino, R. Keyte, A. M. Z. Slawin, D. J. Williams, and J. D. Woollins, "Preparation and single-crystal characterization of $\operatorname{Pr} 2 \mathrm{P}(\mathrm{S}) \mathrm{NHP}(\mathrm{S}) \mathrm{iPr} 2$ and homoleptic $[\mathrm{iPr} 2 \mathrm{P}(\mathrm{S}) \mathrm{NP}(\mathrm{S})$ iPr2]-complexes of zinc, cadmium, and nickel," Inorganic Chemistry, vol. 35, no. 9, pp. 2695-2697, 1996.

[28] M. Afzaal, K. Ellwood, N. L. Pickett, P. O’Brien, J. Raftery, and J. Waters, "Growth of lead chalcogenide thin films using single-source precursors," Journal of Materials Chemistry, vol. 14, no. 8, pp. 1310-1315, 2004.

[29] S.-M. Lee, Y.-W. Jun, S.-N. Cho, and J. Cheon, "Singlecrystalline star-shaped nanocrystals and their evolution: programming the geometry of nano-building blocks," Journal of the American Chemical Society, vol. 124, no. 38, pp. 11244-11245, 2002.

[30] T. Trindade, P. O'Brien, X.-M. Zhang, and M. Motevalli, "Synthesis of PbS nanocrystallites using a novel single molecule precursors approach: X-ray single-crystal structure of $\mathrm{Pb}$ (S2CNEtPri)2," Journal of Materials Chemistry, vol. 7, no. 6, pp. 1011-1016, 1997.

[31] H. Iwasaki and H. Hagihara, "The crystal structure of lead(II) diethyldithiocarbamate," Acta Crystallographica Section B, vol. 28, no. 2, pp. 507-513, 1972.

[32] J. S. Ritch, T. Chivers, K. Ahmad, M. Afzaal, and P. O'Brien, "Synthesis, structures, and multinuclear NMR spectra of tin(II) and lead(II) complexes of tellurium-containing imidodiphosphinate ligands: preparation of two morphologies of phase-pure PbTe from a single-source precursor," Inorganic Chemistry, vol. 49, no. 3, pp. 1198-1205, 2010.

[33] J. Akhtar, M. Afzaal, M. A. Vincent et al., "Understanding the decomposition pathways of mixed sulfur/selenium lead phosphinato complexes explaining the formation of lead selenide," The Journal of Physical Chemistry C, vol. 115, no. 34, pp. 16904-16909, 2011. 